\title{
A gyógyszeres kezelésre nem javuló hirtelen halláscsökkenés lépcsőzetes sebészi terápiája
}

\author{
Kovács Márton dr. ${ }^{1}$ - Uzsaly János dr. ${ }^{1}$ - Bodzai Gréta dr. ${ }^{1}$ \\ Gerlinger Imre dr. ${ }^{1}$ - Szanyi István dr. $^{1}$ - Bakó Péter dr. ${ }^{1,2}$ \\ ${ }^{1}$ Pécsi Tudományegyetem, Általános Orvostudományi Kar, Klinikai Központ, \\ Fül- Orr-Gégészeti és Fej-Nyaksebészeti Klinika, Pécs \\ ${ }^{2}$ Pécsi Tudományegyetem, Általános Orvostudományi Kar, Szentágothai János Kutatóközpont, \\ Regeneratív Medicina Kutatócsoport, Pécs
}

\begin{abstract}
A hirtelen halláscsökkenés patofiziológiája még nagyrészt tisztázatlan, így oki terápia nem lehetséges. Az elsődleges kezelést a helyileg vagy szisztémásan adott kortikoszteroid jelenti, egységes protokoll azonban nem áll rendelkezésre. Nagy vagy súlyos fokú hirtelen halláscsökkenés esetén kóroki tényezőként felmerül a perilymphafistula lehetősége még azoknál a betegeknél is, akiknél nem szerepel trauma az anamnézisben. A kórkép mútéti kezelése a dobüreg feltárását követően a belső fül ablakainak obliterálása. Amennyiben ez a megoldás nem eredményez megfelelő hallásjavulást, hagyományos vagy implantálható hallókészülékek alkalmazása javasolt. A közleményben részletezett esetünkben teljes siketséggel járó, jobb oldali hirtelen halláscsökkenés alakult ki, melynek hátterében egyértelmű okot azonosítani nem sikerült. Az eredménytelen kombinált, intratympanalis és szisztémás szteroidkezelést követően exploratív tympanotomiát végeztünk, melynek során a belső fül ablakait obliteráltuk. Hallásjavulást ezt követően sem sikerült kimutatni, így cochlearis implantáció elvégzése mellett döntöttünk. Az implantációt a kerek ablakon keresztül végeztük, mely alapján kijelenthetjük, hogy az előzetes kerekablak-obliteráció nem zárja ki a későbbi cochlearis implantációt.
\end{abstract}

Orv Hetil. 2021; 162(51): 2055-2060.

Kulcsszavak: cochlearis implantáció, hirtelen halláscsökkenés, kerekablak-obliteráció, perilymphafistula

\section{Staged surgical management of idiopathic sudden sensorineural hearing loss refractory to medical treatment}

The pathophysiology of sudden sensorineural hearing loss is mainly unknown, therefore no causative treatment exists. Systemic and local administration of corticosteroids serves as first line therapy although protocols vary. In cases of severe or profound hearing loss with no improvement for medical therapy, perilymphatic fistulae can be assumed even without any history of trauma. Therefore, inner ear window obliteration as a primary surgical option in the early stage can be considered. For patients without complete recovery, conventional hearing aids or implantable hearing devices can be offered. In our case report, we present a patient with right sided idiopathic sudden deafness. After failure of conservative combined intratympanic and systemic steroid therapy, explorative tympanotomy and obliteration of the inner ear windows were performed. As no hearing improvement was witnessed, successful cochlear implantation via round window insertion was performed. Our case justifies that obliterating the round window membrane does not rule out further successful cochlear implantation.

Keywords: cochlear implantation, perilymphatic fistulae, round window obliteration, sudden sensorineural hearing loss

Kovács M, Uzsaly J, Bodzai G, Gerlinger I, Szanyi I, Bakó P. [Staged surgical management of idiopathic sudden sensorineural hearing loss refractory to medical treatment]. Orv Hetil. 2021; 162(51): 2055-2060.

(Beérkezett: 2021. május 7.; elfogadva: 2021. június 1.) 


\section{Rövidítések}

BAHA $=$ (bone anchored hearing aid $)$ csontvezetéses implantátum; BERA = (brainstem evoked response audiometry) agytörzsi kiváltott válasz audiometria; BiCROS = bilateral microphones with contralateral routing of signal; $\mathrm{CI}=$ cochlearis implantáció; CROS = contralateral routing of signal; $\mathrm{CT}=$ (computed tomography) komputertomográfia; FAF $=$ fissula ante fenestram; ISSNHL = (idiopathic sudden sensorineural hearing loss) idiopathiás hirtelen sensorineuralis halláscsökkenés; $M R=$ mágneses rezonancia; SSNHL = (sudden sensorineural hearing loss) hirtelen sensorineuralis halláscsökkenés

Hirtelen halláscsökkenésnek (sudden sensorineural hearing loss, SSNHL) nevezzük a sensorineuralis halláscsökkenést, amennyiben 3 napon belül alakul ki, és mértéke egymást követő 3 frekvencián eléri a $30 \mathrm{~dB}$-t. Incidenciája 5-27 közöttire tehető 100000 lakosra nézve [1]. A magyarországi esetszámra vonatkozóan nem rendelkezünk adatokkal; egy, a Klinikánkon végzett retrospektív tanulmányban a 2 éves vizsgálati időszak alatt 149 beteget kezeltünk [2]. A leggyakrabban az 50 és 60 év közötti életkorban fordul elő, a nemek között különbség nem mutatható ki.

Az SSNHL hátterében otológiai, neurológiai, cardiovascularis betegségek állhatnak. Külön megemlítendő ok lehet a perilymphafistula kialakulása. Perilymphafistuláról beszélünk, amikor a belső fül folyadéktere és a középfül vagy az intracranium között kóros összeköttetés jön létre; a leggyakrabban barotrauma kapcsán alakul ki [3]. Klasszikus tünete a hirtelen vagy progresszíven kialakuló, esetleg fluktuáló jellegư halláscsökkenés, továbbá a pulzáló fülzúgás és az autofónia. Emellett jelentkezhet zajra (Tullio-jelenség) vagy nyomásemelkedésre (Hennebert-jel) jelentkező szédülés [4].

Mindamellett SSNHL esetén egyértelmú kiváltó okot a legtöbb esetben (70-90\%) nem sikerül feltárni. Ekkor idiopathiás hirtelen halláscsökkenésről beszélünk (ISSNHL). Kialakulásában vascularis, infektív vagy autoimmun eredetet feltételező elméletek ismertek, melyek hátterében közös végpontként a cochlea csökkent oxigénellátottsága állhat [5].

Az ISSNHL diagnózisa akkor mondható ki, ha a halláscsökkenés hátterében potenciálisan előforduló szisztémás (például stroke, hipertenzív krízis, akut veseelégtelenség) vagy helyi (középfülgyulladás, vestibularis schwannoma) ok kizárásra került [6]. Fontos megemlíteni, hogy perilymphafistula barotrauma nélkül is kialakulhat, így állhat az idiopathiás esetek hátterében is. Kiváltképp azoknál merül fel a kórkép lehetősége, akiknél súlyos fokú halláscsökkenés alakul ki, és a konzervatív terápiára nem mutatnak javulást [6-9].

Az ISSNHL kezelése kortikoszteroidtartalmú készítményeken alapul, helyi (intratympanalis), szisztémás (szájon át vagy intravénásan) vagy ezek kombinációjának formájában. A szteroidkezelés hatékonyságát alátámasztó erős evidencia azonban nem ismert $[1,5]$. Válogatott esetekben a halláscsökkenés sebészi kezelése is előtérbe kerülhet. Egyrészről a halláscsökkenés kialakulását követôen rövid időn belül az esetleges perilymphafistula diagnosztizálása és kezelése végezhető el. A dobüreg feltárása (exploratív tympanotomia) során a potenciális „gyenge pontok" vizualizálása (kerek, ovális ablak, fissula ante fenestram $[\mathrm{FAF}]$ ) és lágy résszel történő obliterálása történik. A feltárásnak pontos indikációja nincs, de a szerzők többsége nagy fokú halláscsökkenés $(60 \mathrm{~dB}<)$ esetén javasolja a mútétet, amikor a megelóző gyógyszeres kezelés nem vezet hallásjavuláshoz [3, 6-9]. Amennyiben a mútéti feltárás sem jár eredménnyel, a későbbiekben mútétileg implantálható hallásjavító készülék alkalmazása válhat szükségessé. A közelmúltig az irodalomban nem került leírásra olyan eset, amelyben kerekablak-obliterációt követően cochlearis implantáció (CI) eredményességéről számolnának be. Egy nemrégiben megjelent közleményben azonban egy németországi centrum számol be 21 betegnél sikeresen elvégzett CI-ról, akik korábban SSNHL miatt exploratív tympanotomián estek át [10].

A közleményben a sebészi kezelés lépcsőzetes lehetőségeit mutatjuk be egy esetünk kapcsán. A gyógyszeres kezelésre nem javuló, siketségig fokozódó SSNHL-t elszenvedő betegnél 21 hónappal a hallásjavulást nem eredményező obliteráció után sikeres CI-t hajtottunk végre.

\section{Esetismertetés}

2017 novemberében a Pécsi Tudományegyetem Klinikai Központjának Fül-Orr-Gégészeti és Fej-Nyaksebészeti Klinikáján egy 73 éves férfi jelentkezett 4 nappal korábban kialakult jobb oldali SSNHL-lel, valamint fülzúgással; szédülést nem panaszolt. Tisztahangküszöb-audiometriai vizsgálattal jobb oldalon hallást kimutatni nem tudtunk, bal oldalon kis fokú, $8 \mathrm{kHz}$-en közepes fokú idegi halláscsökkenés volt mérhető ( $1 / A$ ábra). Agytörzsi kiváltott válasz audiometriával (brainstem evoked response audiometry, BERA) jobb oldalon válasz nem volt detektálható. A Klinikánkon alkalmazott protokollnak megfelelően kombinált szteroidkezelésben részesítettük a beteget. Nagy dózisú intravénás metilprednizolon- (3 napig $250 \mathrm{mg}$, majd 2 napig $125 \mathrm{mg}$ ) és naponta dobüregi (intratympanalis) dexametazon- $(0,5-0,7 \mathrm{ml}, 8$ $\mathrm{mg} / \mathrm{ml}$ ) kezelést kapott, összesen 5 napon át. A kezelést követően hallásjavulás nem volt mérhető. Az SSNHL hátterében álló egyéb organikus eltérés kizárása céljából gadolínium kontrasztanyagos 3 Tesla belsőfül-MR-vizsgálatot végeztünk, mely kóros eltérést nem írt le. A beteggel egyetértésben exploratív tympanotomia elvégzése mellett döntöttünk.

A terápia megkezdését követő 7 . napon altatásban végeztük el a mútétet. Endauralis metszést követően a tympanomeatalis lebenyt felemeltük, majd a kellő rálátás érdekében a csontos hallójárat medialis hátsó részét elvettük. A kerek és az ovális ablak, valamint a FAF régiók vizualizációját követően a FAF feletti csontrészt és a kerek ablak fészkét denudáltunk, majd Valsalva-manőver 
mellett perilymphacsorgás jelenlétét kerestük. Esetünkben fistulára utaló eltérés nem volt látható. A periauricularis régióból nyert izomdarabok segítségével a kerek és az ovális ablak, valamint a FAF régiójának obliterációját végeztük el, majd a tympanomeatalis lebeny visszafektetését követően a külső hallójáratot tamponáltuk.

A mútétet követően érdemi hallásjavulás a betegnél nem volt észlelhető, így a binauralis hallás helyreállítása érdekében CI elvégzése mellett döntöttünk ( $1 / B$ ábra). A mútétet 21 hónappal a panaszok megjelenését követően hajtottuk végre facialis idegmonitor segítségével. A „lazy S” bőrmetszést követően limitált mastoidectomiát végeztünk, a kerek ablak fészkét posterior tympanotomia során tártuk fel. A korábbi mütét során a kerek ablak obliterációjára használt lágy részt nehézségek nélkül sikerült eltávolítani, majd az elektródát akadály nélkül vezettük be a csigába a kerek ablak membránjának megnyitását követően (Neuro Zti EVO, Oticon Medical, Vallauris, Franciaország). A mütét után készült CTvizsgálat jó helyzetû́ implantátumot mutatott (2. ábra). Az implantátum 1 hónap múlva került bekapcsolásra, a beteg a hallását az implantátummal kielégítőnek véli. A legutolsó (18 hónappal az implantációt követően) sza- bad hangteres vizsgálattal átlag 30,625 dB-es halláscsökkenés volt mérhető (az 500 Hz, 1, 2, 4 kHz-ek átlagán), beszédértése $50 \mathrm{~dB}$-en 90\%-nak mutatkozott ( $1 / \mathrm{C}$ ábra).

\section{Megbeszélés}

A témában megjelent számos publikáció ellenére az SSNHL pontos patofiziológiájának megismerése és a kórkép oki kezelése még várat magára. A közlemények eredményei gyakran ellentmondásosak, kevés a jól megtervezett és magas szintú tudományos vizsgálat. A betegség jellege miatt a kontrollesetek bevonása nehézkes [5].

Az esetek döntő többségében az SSNHL etiológiája ismeretlen marad (ekkor ISSNHL-ről beszélünk), azonban a lehetséges helyi (fejlődési rendellenesség, gyulladás vagy retrocochlearis eltérés), illetve szisztémás (cardiovascularis, neurológiai, autoimmun, hematológiai) okok kizárása feltétlenül szükséges $[1,5]$.

Az idiopathiás esetek hátterében a leginkább elfogadott elmélet a vascularis teória, mivel a cochleát ellátó arteria labyrinthi funkcionális végartériának tekinthető,
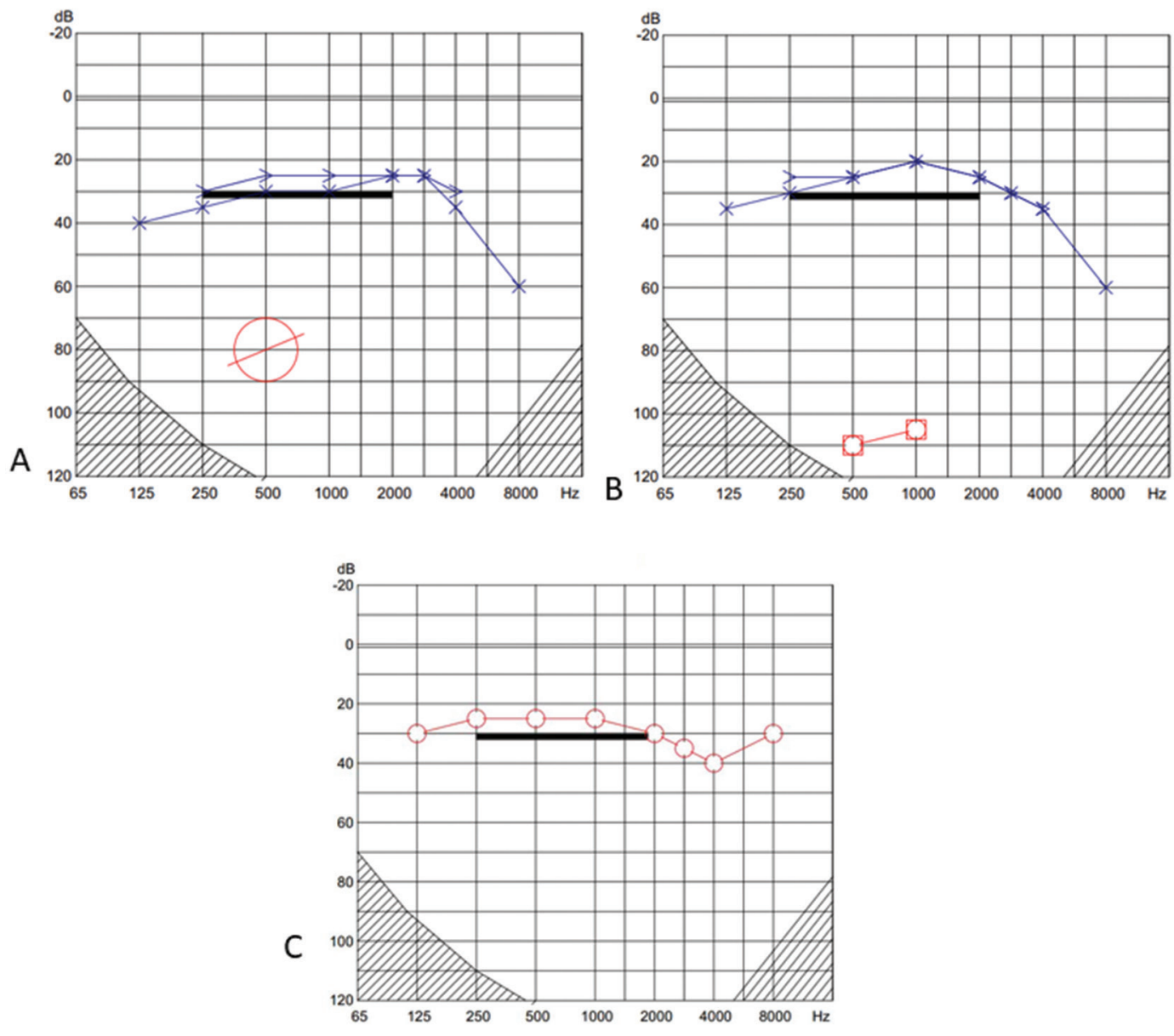

1. ábra $\quad$ A beteg tisztahangküszöb-audiometriai vizsgálatai. A) A kezelést megelőzően készült tisztahangküszöb-audiogram. B) Az obliteráció után mért tisztahangküszöb-audiogram. C) 18 hónappal az implantátum beültetését követően mért, szabad hangtérben készült audiogram 

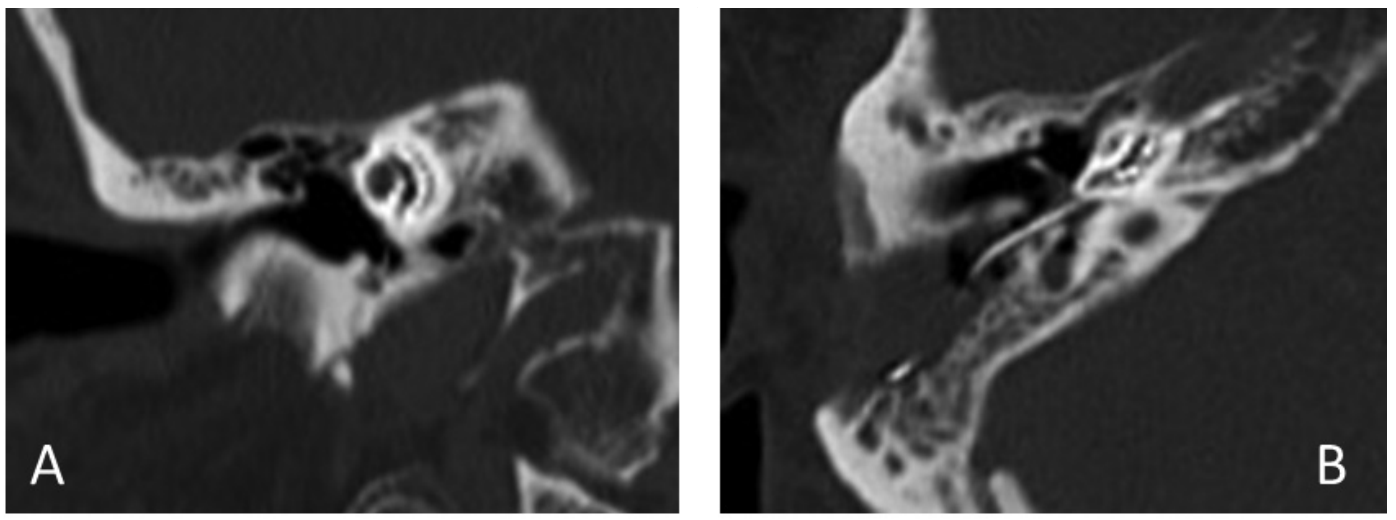

2. ábra

Posztoperatív CT-felvételek. A) Koronális és B) axiális képeken látható a megfelelő helyzetben lévő elektróda

$\mathrm{CT}=$ komputertomográfia

és a hallószerv vérellátásának csökkenése SSNHL-t okozhat. Cardiovascularis betegségben szenvedő egyének esetében gyakrabban alakul ki SSNHL, illetve a hallásjavulás prognózisa is rosszabb $[2,6,10]$. Továbbá az SSNHL-t elszenvedett betegeknél a későbbiekben emelkedett az egyéb akut vascularis betegségek (akut myocardialis infarctus, stroke) előfordulása [10]. Egy másik közkedvelt elmélet a vírusinfekció etiológiai szerepét hangsúlyozza. Egyes feltételezések szerint cochleitis vagy neuronitis alakul ki. Szerológiai vizsgálattal több vírus elleni antitest (mumps, rubeola, kanyaró) is emelkedett szintben volt kimutatható, szerepük azonban a halláscsökkenés kialakulásában nem tisztázott [11]. A harmadik teória, az immunológiai eredet alapja, hogy a vérben keringő autoimmun antitestek a belső fül antigénjeivel keresztreakcióba lépnek. Hirtelen halláscsökkent betegek véréből számos, belső fül elleni antitestet mutattak ki [12].

Az idiopathiásnak vélt esetek egy részében fel nem ismert perilymphafistula is jelen lehet, mivel az spontán, trauma nélkül is kialakulhat [3]. A fistula kialakulásának nincs specifikus lokalizácója, az ovális és a kerek ablak membránjának rupturája a leggyakoribb predilekciós helyek. Emellett Tóth és mtsai feltételezték elsőként a FAF területén jelentkező perilymphacsorgás kóroki szerepét SSNHL esetén. A FAF a csontos labyrinthus ritka anatómiai variációja, mely az ovális ablaktól anterior helyezkedik el [9]. Mivel a perilymphafistula bizonyossággal sem fizikális vizsgálattal, sem képalkotókkal nem mutatható ki, a hagyományos kezelésre nem javuló, súlyos vagy siketségig fokozódó SSNHL esetén exploratív tympanotomia elvégzése jön szóba a lehetséges perilypmphacsorgás, valamint membránruptura megítélésére. Azonban a diagnosztikus és egyben terápiás mútéti feltárásnak pontos indikációja nem ismert, így az irodalmi adatok is szerteágazóak [5, 6, 8, 13]. Klinikánkon legalább 60 dBes halláscsökkenés esetén végezzük el a műtétet, ha az 5 napos szteroidkezelést követően nem tudunk javulást elérni $(<10 \mathrm{~dB})$.
További diagnosztikai bizonytalanságot szül, hogy a negatív mütéti lelet ellenére sem lehet elvetni a perilymphafistula esetleges kóroki szerepét [7]. Prenzler és mtsai kimutatták, hogy a hallásjavulás mértéke nem függ attól, hogy a mütét során sikerült-e definitív fistulát kimutatni. Ennek magyarázata egyrészről az lehet, hogy bár a perilymphafistula jelen volt, az lezárásra került anélkül, hogy a mútét kapcsán ez kimutatható lett volna [8]. Így negatív mütéti lelet (perilymphafistula hiánya) esetén is javasolható az obliteráció elvégzése.

Thomas és mtsai nagy beteganyagon vizsgálták a lehetséges prognosztikai tényezóket. A magasabb életkor, a cardiovascularis társbetegségek megléte és a siketség mértékét elérő halláscsökkenés negatívan befolyásolta a kimenetelt. Továbbá azon betegeknél, akiknél az anamnézisben barotrauma igazolódott, nagyobb valószínúséggel fordult elő hallásjavulás a mútétet követően [6]. A kezelés hatásossága $24 \%$ és $100 \%$ között változik, a hallásjavulás mértéke is jelentős különbségeket mutat $(12,4 \mathrm{~dB}$ és $42 \mathrm{~dB})[5,6,8,9]$. A teljes hallásjavulás is változó, átlaga az irodalomban $28 \%$ körüli, így megállapítható, hogy a gyógyult esetek száma alacsony, a betegek többségénél további hallásrehabilitációra van szükség [6].

A sikertelen kezelést követően visszamaradó halláscsökkenés az életminőség csökkenéséhez vezethet. Ilyenkor nagyrészt féloldali halláscsökkenés vagy egyoldali siketség áll fenn. Ezen betegeknél elsősorban az irányhallás romlik, zajos környezetben a beszédértés okoz nehézséget; ennek következtében a beteg kerüli ezeket a helyzeteket, ami szociális izolációhoz vezethet [14].

A cél ezen esetekben a binauralis hallás rehabilitálása. A halláscsökkenés mértékétől függően a kezelés elsődlegesen választandó eszköze a hagyományos hallókészülék. Amennyiben hagyományos készülékkel maximális erősítés mellett sem érhető el kielégítő beszédértés, CROS (contralateral routing of signal) hallókészülék alkalmazására van lehetőség. A CROS-rendszer lényege, hogy a rosszul halló fülön viselt eszköz által felfogott hangokat a készülék az ép fülben lévő hallókészülékbe 
továbbítja. BiCROS (bilateral microphones with contralateral routing of signal) eszköz akkor alkalmazható, ha az ellenoldali fülön is észlelhetố halláscsökkenés. Ezen hallókészülék-típus több hátránya is ismert: a binauralis hallás csak kismértékben adható vissza, zajos környezetben a beszédértés általában nem kielégítô [15]. Az implantálható hallókészülékek egyoldali siketség esetén is egyre szélesebb körben kerülnek alkalmazásra. A csontvezetéses implantátumok közül a BAHA és a Bonebridge alkalmazása terjedt el a gyakorlatban. Csontvezetéses implantátumokkal bilaterális hallás úgy érhető el, hogy az érintett oldalra beültetett implantátumból az ellenoldali ép belső fülbe jut el a rezgés. Ez a módszer csak akkor alkalmazható, ha az ellenoldali fülön a halláscsökkenés mértéke nem haladja meg a $20 \mathrm{~dB}$-t [16]. A CROS-rendszerrel és a csontvezetéses implantátumokkal azonban csak úgynevezett „pseudobinauralis” hallás érhetó el, szemben a CI-val, amely ténylegesen az érintett oldalon képes a hallás rehabilitálására. A CI indikációja a súlyos fokú, süketséggel határos halláscsökkenés, amikor szabad hangtérben a beszédértés - optimálisan illesztett hallókészülékkel - $65 \mathrm{~dB}$-en $50 \%$ alatt marad. Először 2008-ban Van de Heyning és mtsai publikálták féloldali siketség esetén történő sikeres alkalmazását, 22 betegből 3 esetben volt a mútét indikációja SSNHL [17]. Arndt és mtsai a CROS-szal, BAHA-val és CI-val szerzett eredményeket hasonlították össze: a zajos környezetben való beszédértést és a hang forrásának lokalizációját vizsgálva is a CI előnyét mutatták ki. 11 betegükből 6-nál SSNHL volt a nagyothallás hátterében [16].

Egészen a közelmúltig nem számoltak be olyan esetről, amelynél sikertelen kerekablak-obliteráció után CI-t végeztek volna. Közleményünkkel közel egy időben publikálták egy retrospektív vizsgálat eredményét. Az elemzésbe 21 , hirtelen halláscsökkent beteget választottak be, akik korábban sikertelen konzervatív kezelést követően kerek- és oválisablak-obliteráción estek át, de ettől sem következett be hallásjavulás, ezért CI-t végeztek. Az implantáció során, saját tapasztalatainkhoz hasonlóan, a korábbi beavatkozáshoz köthetô nehézség nem adódott. Az implantátummal jó halláseredményekről számoltak be [10].

Esetünkben csontvezetéses implantátum alkalmazása nem jött szóba a féloldali siketség rehabilitálására, mivel az egészséges fülön is közepes fokú hallácsökkenés volt mérhetó, ezért a CI mellett döntöttünk. A korábbi mútét során a perilymphafistula obliterálása céljából a kerek ablak fészkéhez behelyezett lágy részt a CI mútéte során akadály nélkül eltávolítottuk, így az elektródát a kerek ablakon át tudtuk a csigába behelyezni. Ez kiemelt jelentőségú, hisz az ily módon elvégzett implantációtól várható a mútét utáni legjobb eredmény [18]. A beteg az implantátumot rendszeresen használja, hallásával jelenleg elégedett. A mútétet követôen készült szabad hangteres vizsgálatokkal az implantátum megfelelő múködéséről győződhettünk meg.

\section{Következtetés}

SSNHL-t elszenvedett betegeknél a sikertelen konzervatív kezelés esetén az ovális és a kerek ablak, valamint a FAF lágy résszel történő obliterálása hatékony kezelési lehetőség lehet. Ha a hallásjavulás mértéke nem kielégítő, további hallásrehabilitáció válik szükségszerúvé a binauralis hallás helyreállítására. Féloldali siketség esetén kizárólag CI elvégzésével érhetô el tényleges binauralis hallás. A cochlearis implantátum elektródájának behelyezése során semmilyen nehézségbe nem ütköztünk, így elmondható, hogy féloldali siketség esetén a kerek ablak obliterációját követően is sikeresen elvégezhetô a CI.

Anyagi támogatás: A közlemény elkészítése anyagi támogatásban nem részesült.

Szerzői munkamegosztás: K. M., U. J.: Adatgyüjtés, irodalomkutatás. K. M., B. P.: A kézirat megírása. K. M., B. G., G. I., Sz. I., B. P.: A beteg gyógykezelésében vettek részt. A cikk végleges változatát valamennyi szerző elolvasta és jóváhagyta.

Érdekeltségek: A szerzőknek sem pénzügyi, sem személyes vagy egyéb érdekeltségük nincs.

\section{Irodalom}

[1] Chandrasekhar SS, Tsai Do BS, Schwartz SR, et al. Clinical practice guideline: sudden hearing loss (update). Otolaryngol Head Neck Surg. 2019; 161(1_Suppl): S1-S45.

[2] Kovács M, Uzsaly J, Bodzai G, et al. Analysis of prognostic factors influencing the effectiveness of treatment in sudden sensorineural hearing loss. [A hirtelen halláscsökkenés javulásában szerepet játszó prognosztikai faktorok vizsgálata.] Orv Hetil. 2019; 160: 687-693. [Hungarian]

[3] Deveze A, Matsuda H, Elziere M, et al. Diagnosis and treatment of perilymphatic fistula. Adv Otorhinolaryngol. 2018; 81: 133145.

[4] Kalinics P, Gerlinger I, Révész P, et al. Third window syndrome - classification, diagnosis, therapy. [Harmadikablak-szindróma osztályozás, diagnózis, terápia.] Orv Hetil. 2020; 161: 19441952. [Hungarian]

[5] Plontke SK. Diagnostics and therapy of sudden hearing loss. GMS Curr Top Otorhinolaryngol Head Neck Surg. 2018; 16: Doc05.

[6] Thomas JP, Drewermann S, Voelter C, et al. Prognostic factors regarding the hearing outcome in severe to profound sudden sensorineural hearing loss treated by tympanotomy and sealing of labyrinthine windows after ineffective systemic corticosteroid application. Eur Arch Otorhinolaryngol. 2018; 275: 17491758.

[7] Gedlicka C, Formanek M, Ehrenberger K. Analysis of 60 patients after tympanotomy and sealing of the round window membrane after acute unilateral sensorineural hearing loss. Am J Otolaryngol. 2009; 30: 157-161.

[8] Prenzler NK, Schwab B, Kaplan DM, et al. The role of explorative tympanotomy in patients with sudden sensorineural hearing loss with and without perilymphatic fistula. Am J Otolaryngol. 2018; 39: 46-49. 
[9] Tóth M, Roesch S, Grimm A, et al. The role of fissula ante fenestram in unilateral sudden hearing loss. Laryngoscope 2016 ; 126: $2823-2826$.

[10] Rupp R, Hornung J, Balk M, et al. Cochlear implantation following explorative tympanotomy in patients with sudden sensorineural hearing loss: surgical features and audiological outcomes. Ear Nose Throat J. 2021 Apr 13. Doi: 10.1177/ 1455613211009141. [Epub ahead of print]

[11] Veltri RW, Wilson WR, Sprinkle PM, et al. The implication of viruses in idiopathic sudden hearing loss: primary infection or reactivation of latent viruses? Otolaryngol Head Neck Surg. 1981; 89: 137-141.

[12] Boulassel MR, Deggouj N, Tomasi JP, et al. Inner ear autoantibodies and their targets in patients with autoimmune inner ear diseases. Acta Otolaryngol. 2001; 121: 28-34.

[13] Kampfner D, Anagiotos A, Luers JC, et al. Analysis of 101 patients with severe to profound sudden unilateral hearing loss treated with explorative tympanotomy and sealing of the round window membrane. Eur Arch Otorhinolaryngol. 2014; 271: $2145-2152$.

[14] Hwa TP, Sturm JJ, Losenegger T, et al. Impact of underlying diagnosis on speech and quality of life outcomes after cochlear implantation for single-sided deafness. Otol Neurotol. 2020; 41: e432-e440.

[15] Snapp H. Nonsurgical management of single-sided deafness: contralateral routing of signal. J Neurol Surg B Skull Base 2019; 80: $132-138$

[16] Arndt S, Aschendorff A, Laszig R, et al. Comparison of pseudobinaural hearing to real binaural hearing rehabilitation after cochlear implantation in patients with unilateral deafness and tinnitus. Otol Neurotol. 2011; 32: 39-47.

[17] Van de Heyning P, Vermeire K, Diebl M, et al. Incapacitating unilateral tinnitus in single-sided deafness treated by cochlear implantation. Ann Otol Rhinol Laryngol. 2008; 117: 645-652.

[18] Adunka O, Unkelbach $\mathrm{MH}$, Mack M, et al. Cochlear implantation via the round window membrane minimizes trauma to cochlear structures: a histologically controlled insertion study. Acta Otolaryngol. 2004; 124: 807-812.

(Kovács Márton dr., Pécs, Munkácsy M. u. 2., 7621 e-mail: kovacs.marton@pte.hu)

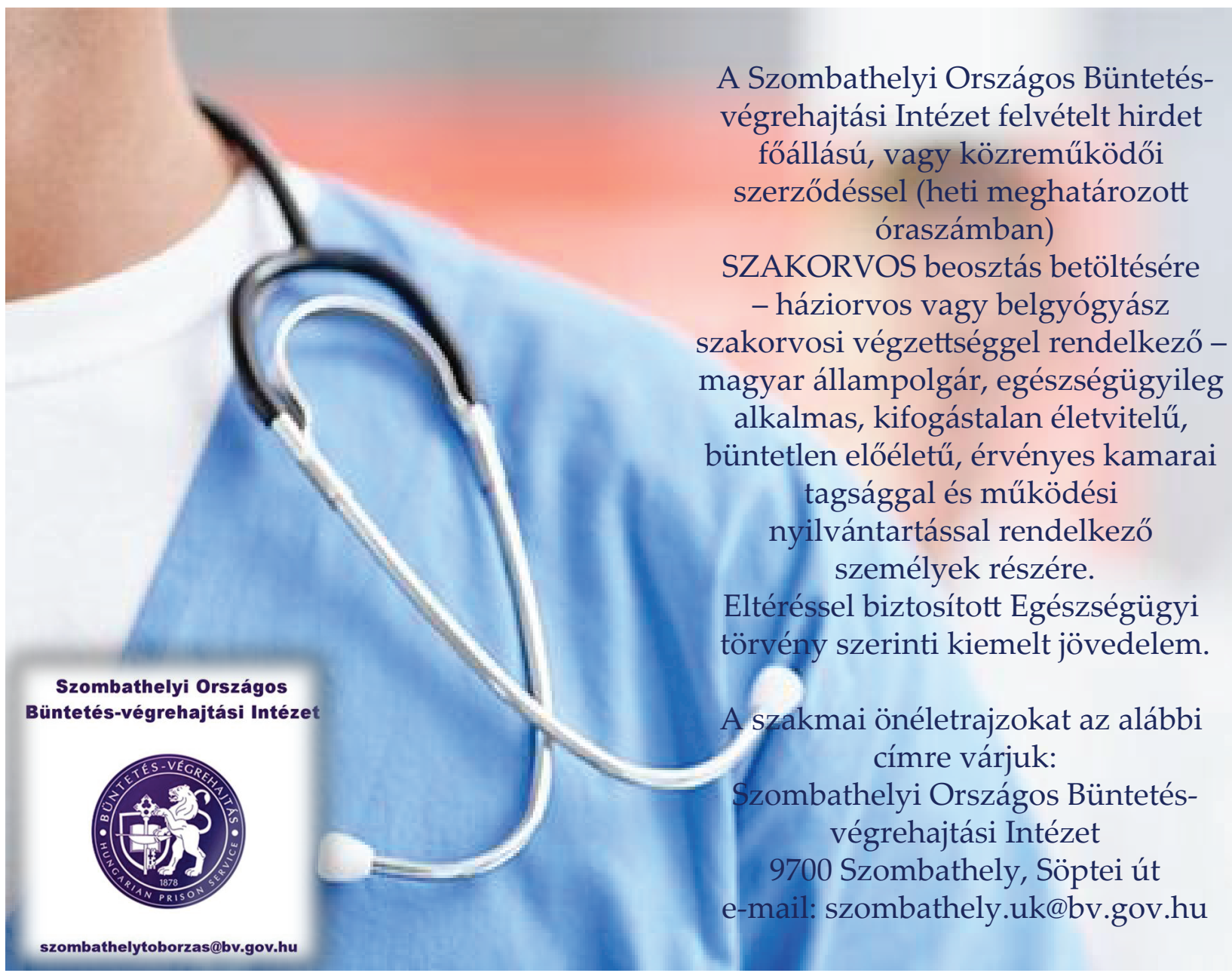

A cikk a Creative Commons Attribution 4.0 International License (https://creativecommons.org/licenses/by/4.0/) feltételei szerint publikált Open Access közlemény, melynek szellemében a cikk bármilyen médiumban szabadon felhasználható, megosztható és újraközölhető, feltéve, hogy az eredeti szerző és a közlés helye, illetve a CC License linkje és az esetlegesen végrehajtott módosítások feltüntetésre kerülnek. (SID_1) 